\title{
Factors associated with the structural liquidity of banks in Brazil ${ }^{\star}$
}

\author{
Vanessa Rodrigues dos Santos Cardoso' \\ (D) https://orcid.org/0000-0002-2124-2282 \\ Email: vanessarscardoso@hotmail.com \\ Lorena Almeida Campos ${ }^{1}$ \\ (D) https://orcid.org/0000-0001-6447-3294 \\ Email: lorenacampos@unb.br \\ José Alves Dantas ${ }^{1}$ \\ (D) https://orcid.org/0000-0002-0577-7340 \\ Email: josealvesdantas@unb.br \\ Otávio Ribeiro de Medeiros ${ }^{1}$ \\ (D) https://orcid.org/0000-0003-4095-6392 \\ Email: otavio@unb.br \\ 1 Universidade de Brasília, Faculdade de Economia, Administração, Contabilidade e Gestão Pública, Departamento de Ciências Contábeis e \\ Atuariais, Brasília, DF, Brazil
}

Received on 07.25.2017 - Desk acceptance on 12.04.2017 - $4^{\text {th }}$ version approved on 09.22.2018 - Ahead of print on 02.18.2019

Associate Editor: Fernanda Finotti Cordeiro Perobelli

\begin{abstract}
This study aimed to identify the relationship between the Structural Liquidity Index (SLI) and macroeconomic variables, bank characteristics, and the validity period of the Basel III Agreement. Although the academic discussion on bank liquidity essentially addresses short-term issues, monitoring long-term liquidity helps assess any excessive dependency of banks on unstable resources, thus contributing to mitigating the risks of systemic liquidity crises such as that of 2008. As it provides evidence of the relationship between the SLI and the selected explanatory variables, the study can be included in the context of the discussions involving the Basel III Agreement, which establishes the implementation of the long-term liquidity index regulatory requirement as of 2018. The model was formulated based on fourteen research hypotheses, tested using panel data regressions estimated via pooled ordinary least squares, least squares with fixed effects, and two-stage least squares with fixed effects. The dependent variable was constructed based on the accounting data of 184 conglomerates and individual financial institutions operating in the country between June 2002 and December 2014. The SLI presented a positive relationship with changes in the exchange rate, international reserves, and reserve requirements, as well as with the profitability, size, and main specialization of the institution. On the other hand, we found a negative relationship between the SLI and the basic interest rate, country risk, balance of trade, validity period of the Basel III Agreement, type of equity control (private vs. government), and the bank being publicly listed on the São Paulo Stock, Commodities, and Futures Exchange (BM\&FBovespa) or privately held. The validation of the relationships between these explanatory variables and the SLI provides a broader understanding of the risks to which financial institutions are exposed, contributing to the preventive analysis of bank liquidity risk - an antecedent indicator of financial crises, diminished confidence, and economic instability.
\end{abstract}

Keywords: structural liquidity, banking institutions, Basel III, banks, liquidity risk.

Correspondence address

Vanessa Rodrigues dos Santos Cardoso

Universidade de Brasília, Faculdade de Economia, Administração, Contabilidade e Gestão de Políticas Públicas, Departamento de Ciências Contábeis e Atuariais

Campus Universitário Darcy Ribeiro, Bloco A-2 - CEP 70910-900

Asa Norte - Brasília - DF - Brazil

*Article presented at the 2nd UnB Accounting and Governance Conference, Brasília, DF, Brazil, November 2017. 


\section{INTRODUCTION}

The aim of this article is to identify the relationship between the structural liquidity of the banking institutions that carry out their activities in the Brazilian market and macroeconomic variables, the individual characteristics of the institutions, and sensitivity to the validity period of the Basel III Agreement.

According to Krishnamurthy, Bai, and Weymuller (2016), bank liquidity performs an important role during financial crises. For example, as a result of the most recent global financial crisis, government guarantees to the biggest European banks exceeded $€ 1.4$ trillion. During the same period, in the United States, the injection of resources into Fannie Mae and Freddie Mac alone totaled US $\$ 200$ billion. Issues such as these have drawn attention to the need to discuss more objectively the liquidity of financial institutions (Borça \& Torres, 2008; Cardoso, 2013; Flannery \& Giacomini, 2015).

It was due to recognizing the important role of liquidity in the 2008 crisis that the Basel Committee introduced, in 2009, the liquidity regulation for commercial banks (Krishnamurthy et al. 2016). At the time, a series of proposals were announced to strengthen the banking structure, known as the Basel III Agreement: (i) reinforcement of the global capital framework; (ii) introduction of a leverage index; (iii) minimum capital requirements; and (iv) different treatment for large institutions that are relevant to the global financial system, also known as "too big to fail".

The Basel III Agreement defined two new liquidity requirements: the liquidity coverage ratio (LCR) and the net stable funding ratio (NSFR), with two distinct, but complementary objectives. The LCR contemplates liquidity questions of a short-term nature, while the NSFR addresses the same aspects, but from a medium and longterm standpoint (Cardoso, 2013).

According to Bonfin and Kim (2012), these measures aim to prevent banks from being excessively dependant on short-term loans, since the systemic risk would inevitably increase if many banks adopted this strategy. Thus, the indicators proposed in Basel III aim to expand the scope of liquidity risk assessments in the banking system.

As part of the bank supervision and liquidity risk monitoring process, the Brazilian Central Bank (CB) publishes the liquidity index (LI), equivalent to the LCR, aggregated for the whole banking system, and it simulates a stress scenario with a 30-day timeframe (Tabak, Guerra, Miranda \& Souza, 2012). The CB has also developed the structural liquidity index (SLI) to assess the continuity and viability of banking activities, incorporating the objectives of the NSFR. These indicators were added to the Brazilian regulations, requiring minimum compliance as of 2016 for the LI (LCR) and as for 2018 for the SLI (NSFR).

Within academia, the debate regarding bank liquidity has mainly taken place via studies such as those by Aspachs, Nier, and Tiesset (2005), Oreiro (2005), Gonçalves and Braga (2008), Silva (2009), Vodova (2011a, 2011b), Tabak et al. (2012), Malik and Rafique (2013), Vinhado and Belém (2013), Vasconcelos (2014), and Moussa (2015). Although these studies reveal various aspects related to bank liquidity, they essentially address short-term liquidity. In regard to long-term structural liquidity, the object of this study, the discussions are much more in their infancy.

The need to observe the influence of the economic environment over bank liquidity is demonstrated by the fact that the Brazilian Central Bank (CB, 2015) simulates "extreme and adverse changes in the main economic and financial variables", called capital stress tests, with the purpose of "measuring resistance, as well as the capacity to absorb losses caused by any materialization of the main risks to which the banking system is exposed". For Tabak et al. (2012), liquidity stress tests are very useful for assessing whether banks present specific liquidity weaknesses.

Gonzales-Hermosillo (1999), for example, suggests that macroeconomic variables can capture the factors that weaken banks, while Aita (2010) considers studies that identify the macro- and microeconomic factors that affect financial institutions to be relevant, in order to avoid crises of confidence and economic imbalances. In regard to this aspect, Tirole (2011) states that macroeconomic questions are fundamental for institutions and for providing liquidity and they should be considered in systemic risk models.

Thus, in the literature on the banking sector, the niche of this study is structural liquidity, which has a different focus in relation to short-term liquidity, since it refers to the management of resources in order to support long-term lending operations. The study differs from previous studies by investigating, using an econometric model, whether macroeconomic and regulatory variables and the individual characteristics of banks can affect their structural liquidity. In a wider sense, by identifying empirical evidence regarding which variables affect the 
structural liquidity of banks, this study contributes to the development of the literature with respect to aspects that can influence the health of the banking system and lending in the real economy.

Based on the relationships suggested by the literature, panel data regressions were estimated using the pooled least squares method, testing a model formulated based on 14 hypotheses concerning the relationship between the variables of interest and structural liquidity, a dependent variable constructed based on the accounting data of 184 banking institutions and conglomerates operating in Brazil between June 2002 and December 2014.

The use of these variables broadens the understanding of the risks to which the institutions are exposed, in order to assess any excessive dependency of the banks on unstable resources, contributing to the preventative analysis of bank liquidity risk - an antecedent indicator of financial crises, diminished confidence, and economic imbalances.

\section{THEORETICAL FRAMEWORK}

By means of financial intermediation, banks provide the liquidity that makes investment and consumption possible, by guaranteeing resources for investors and consumers. According to Diamond and Dybvig (1983), in a financial system where there is confidence, the risks are shared among agents. However, suspicion about the possibility of a bank failing can cause a bank run by depositors to withdraw their deposits, including those who would prefer to maintain them if they were not worried. In this scenario, the bank is obliged to liquidate its assets, even at a loss, and even if not all depositors withdraw their funds. In other words, the same deposits that enable banks to provide liquidity to the real economy are those that leave them vulnerable to bank runs caused by a crisis of confidence.

Bank runs are the most common characteristic of the extreme crises that have played a leading role in monetary history. They cause real economic problems because even healthy banks can fail, interrupting loans and paralyzing productive investments. Bank runs are costly and reduce social well-being by interrupting production and destroying optimal risk-sharing among depositors, thus causing economic problems (Diamond \& Dybvig, 1983).

As they are exposed to various related risks, the complexity of banks has grown over time (Bonfin \& Kim, 2012; Cardoso, 2013). According to Cardoso (2013), they have taken on greater responsibility with thirdparty resources, given the greater representativeness in comparison to own capital. Banks capture resources with lower maturities than those with which they grant credit and, in this time gap, they can incur liquidity risk, which is characterized by insufficient resources to honor commitments (Gonçalves \& Braga, 2008).

Financial crises, as Capelletto (2006) warns, cause imbalances in the economy. Initially in the United States, but subsequently spreading to other countries, there was a loss of market confidence in the solvency and liquidity of many banks during the worst point of the 2008 crisis, which quickly spread to the rest of the system and to the real economy, resulting in a contraction of liquidity and credit. Finally, the public sector intervened by providing liquidity, capital, and guarantees, exposing tax payers to considerable losses (Gideon, Petersen, MukuddemPetersen \& Hlatshwayo, 2013).

\subsection{Liquidity Risk and the Basel Agreements}

According to Resolution n. 4,090/2012 of the National Monetary Council (Brazilian Central Bank - CB, 2012), liquidity risk is defined as the possibility of a financial institution not being able to "efficiently honor its expected and unexpected current and future obligations" or "to trade the market price of a position, due to its large size in relation to the volume normally traded or as a result of some discontinuity in the market".

According to Mishkin and Eakins (2012), defaults in the subprime mortgage market overwhelmed the market in 2008, leading to the worst financial crisis in the United States since the great depression. This crisis left behind various lessons, one of the most important being the need to establish regulations for liquidity risk (Bonfin \& Kim, 2012).

This incentivized an overhaul of Basel II and the introduction of new propositions that resulted in the Basel III Agreement. For Cardoso (2013), this agreement incentivizes more prudence and transparency in bank fund-raising operations, by means of instruments that provide a lower risk propensity and stimulate leveraging. It also introduces a reflection of the impact of systemic risk, which shows the need for more substantive supervision by requiring institutions to present better quality indices, enabling microprudential supervision to be complemented by macroprudential supervision.

The new regulation establishes two liquidity indicators that will be internationally required from 
financial institutions: the LCR, which indicates the level of short-term liquidity, already incorporated into the rules of Brazil as of October 2015 for institutions with total assets greater than R $\$ 100$ billion; and the NSFR, which refers to structural liquidity and which, according to an agreement between the G20 countries, will be implemented as of 2018. The NSFR is a longterm structural ratio that objectifies avoiding liquidity imbalances and incentivizing banks to use stable sources to finance their activities.

From a bank supervision perspective, these indicators enable liquidity to be monitored and the consistency of cross-inspection to improve, helping supervisors to identify and assess trends in bank liquidity risk and anticipate systemic risks (Gideon et al. 2013).

Regarding the NSFR requirement, there are criticisms, the main ones being: (i) it may be very restrictive and harm banks' liquidity and maturity transformation activities; (ii) it may make deposits less stable as banks compete for this scarce source of funding; (iii) it may incentivize the migration from maturity and liquidity transformation activities towards shadow banking; and (iv) it may significantly affect emerging and developing markets, which tend to have less developed capital markets and depend on long-term funding from banks (Gobat, Yanase \& Maloney, 2014). In addition, maintaining liquidity and equity levels in accordance with the regulatory requirements generates costs that can have an impact on gross domestic product (GDP), in the short and medium-term, a reason for which 2018 was defined as the deadline for implementation (Gideon et al. 2013).

Other consequences of implementing NSFR indicated by King (2013) may derive from different behavioral responses to the regulation involving liquidity. Thus, banks that are not able to reach the minimum stipulated requirement may opt to change the structure of their balance sheets and alter the composition or maturity of their loans or of their investments. But these strategies would have costs for the economy as a whole, configuring the trade-off between regulating liquidity, bank risk, and return, in addition to their being a lack of experience of liquidity regulation, which creates the potential for unintentional consequences (King, 2013).

It is important to highlight the observation made by DeYoung and Jang (2016), that these liquidity and lending indices were not invented by the banking supervisors and regulators, since they are practiced by many banks in the United States as a way of diagnosing liquidity risks.

\subsection{Bank Structural Liquidity}

Structural liquidity is defined as managing the sources of funds so that they are stable enough to support longerterm lending operations. This means that the greater the stability of the resources, the lower the risk of them being insufficient in the future (CB, 2015). In this sense, the CB, which had already developed the LI, incorporated into their monitoring the rationality introduced by the NSFR via the SLI within the regulatory framework of Basel III. The SLI has already been reported in aggregate form and without the $\mathrm{CB}$ opening up the data since 2015, via the Financial Stability Report (FSR), and it will be required of financial institutions as of 2018.

According to the CB (2015), the SLI is represented by the ratio between (i) "stable resources available", composed of funds raised by the institution that it expects to maintain over a one-year timeframe (third-party resources) and its capital (own resources); and (ii) "stable resources needed", formed of total assets, including off-balance sheet assets, with maturities greater than one year and/or with low liquidity. The calculation of the numerator and of the denominator is based on the sum of the balances of the liability (including equity) and asset accounts, respectively, after applying weighting factors that reflect the degree of collectability and liquidity of these components. Thus, an adequate funding structure for the type of business of the financial institution occurs when the SLI is equal to or greater than $1(100 \%)$, in which case it is less susceptible to future liquidity problems (CB, 2015).

DeYoung and Jang (2016) explain that the main difference between the obligatory standards of Basel III and the reference liquidity indices used by banks in the United States (it is possible to link these with the SLI reported by the CB) is that the former, after its implementation, imposes a degree of liquidity linked to the bank's level of lending. Thus, banks that have liquidity indices that are low or close to the minimum necessary will need to adopt measures so that the balance of their "liquidity buffers" complies with the new standards required by Basel III.

\subsection{Development of the Research Hypotheses}

Given that the purpose of the study is to identify the relationship between the structural liquidity of financial institutions in Brazil and macroeconomic variables, the characteristics of the institutions, and sensitivity to the implementation of Basel III, 14 research hypotheses were formulated based on the relationships suggested in the literature. The explanatory power of these variables 
provides a broader understanding of the risks to which the financial institutions are exposed.

Keynes' Liquidity Preference Theory states that banks favor return over liquidity when expectations are optimistic regarding an uncertain future; that is, the strategies of banks consider the trade-off between return and liquidity (Paula, 1998; Paula \& Lima, 1999). This effect supports the findings of Dantas, Medeiros, and Capelletto (2011) and those of Primo, Dantas, Medeiros, and Capelletto (2013), who, when examining the determinants of ex-post bank spread and return, respectively, verified a positive relationship between economic activity and bank profitability.

In studies on bank liquidity, Aspachs et al. (2005), Vodova (2011a), and Vinhado and Belém (2013) declared that GDP growth is negatively related with liquidity levels. That is, banks maintain lower liquidity levels in periods of accelerated growth; in contrast, they build up their liquidity buffers during economic recessions. This assumption gives rise to the first research hypothesis:

$\mathrm{H}_{1}$ : the structural liquidity of banking institutions in Brazil is negatively related with the level of economic activity in the country.

According to Luporini and Alves (2010), the investment decisions of entrepreneurs are the result of an intertemporal choice between retaining universally liquid assets (currency) and creating specific liquidity assets (investment), comparing the interest rate and the expected return on investment, under conditions of uncertainty, the former being a form of reward for not choosing liquidity.

The results of Aspachs et al. (2005) suggested that in the United Kingdom the short-term interest rate appeared to affect liquidity buffers; that is, when the monetary authority tries to stimulate the economy by reducing the interest rate and correspondingly increasing the monetary base, there is a delay in the effects being transmitted, since the banks appear to maintain additional liquidity buffers on their balance sheets.

Oreiro (2005) and Vinhado and Belém (2013) perceived a negative relationship between liquidity and the interest rate. In contrast, Silva (2009) and Vodova (2011a) found a positive relationship between the interest rate and bank liquidity and explain that this is due to the incentives to save more when interest rates rise, which increases bank liquidity - borrowers avoid more costly credit operations (which are most of banks' long-term investments). Along the same lines, stable resources decrease, with the aim of taking advantage of short-term gains derived from the interest rate volatility. This reduction tends to be proportionally greater than the reduction in long-term investments. With this, it is inferred that:

$\mathrm{H}_{2}$ : the structural liquidity of banking institutions in Brazil is negatively related with the level of the interest rates.

Primo et al. (2013) identified a negative relationship between exchange rate variations and bank profitability, attributing this effect to the fact that banks are unable to adequately anticipate exchange rate variations, which negatively influences their performance. The authors highlight that exposure to exchange rate risk is limited to $30 \%$ of reference equity by regulatory determination.

Analyzing the relationship between exchange rate appreciation and bank insolvency, Aita (2010) found a positive relationship. Thus, based on the assumption that banks do not anticipate exchange rate variations and that the effect of these on liquidity depends on their exposure (which is limited), as well as on the results of previous research, the following hypothesis is formulated:

$\mathrm{H}_{3}$ : the structural liquidity of banking institutions in Brazil is positively related with variations in the exchange rate.

Country-risk is a type of external vulnerability measure that reflects aversion to the risk inherent to a particular economy. In the study by Manhiça and Jorge (2012) on bank spread, country-risk behavior indicated that when there is a deterioration in the country's risk classification, there will be an increase in the interest rate margin practiced by banks. In a study on international liquidity, Resende and Amado (2007) state that Brazilian companies carry out their analyses (of their capacity to fulfill obligations) in accordance with their cash flows, while financial institutions verify both projected cash flow and the country's vulnerability. Thus, the assumption will be tested that country-risk aversion would cause an outflow of foreign resources from Brazil towards countries that are considered as safer and this, consequently, would reduce the liquidity of Brazilian banks, even structural liquidity, giving support to the following hypothesis:

$\mathrm{H}_{4}$ : the structural liquidity of banking institutions in Brazil is negatively related with the Brazil-risk.

Aita (2010) found that a reduction in the balance of trade contributes to bank insolvency, considering that this is also caused by a lack of liquidity. In contrast, Resende and Amado (2007) found a strong and negative correlation between the international LI and Brazil's current account balance of payments caused by the economy's lack of competitiveness, low product diversification, and export 
competitiveness on the international market. In other words, at times of economic growth, the balance of trade would tend to deteriorate due to the net inflow of resources into the balance of payments, which tends to stimulate the growth of stable resources more than proportionally to long-term investments. This context supports the following hypothesis:

$\mathrm{H}_{5}$ : the structural liquidity of banking institutions in Brazil is negatively related with the balance of trade.

According to Resende and Amado (2007), increases in the international reserves of peripheral countries are exlained by expansions in the supply of international liquidity and by these economies absorbing international resources available for lending when there are facilities. In expansionary periods of the international liquidity cycles, the uncertainties in the peripheral economies are minimized, enabling an expansion of credit. Positive variations in the net inflow of foreign resources into the balance of payments expand the supply of credit, mitigating creditor countries' preference for liquidity. This reasoning is inverted in contractionary phases of the international liquidity cycle, when international creditors increase their preference for liquidity, which materializes through the purchase of foreign assets, characterizing the movement known as capital flight. This is the basis for the next hypothesis:

$\mathrm{H}_{6}$ : the structural liquidity of banking institutions in Brazil is positively related with the level of international reserves in the economy.

The United States provides international liquidity as it is the biggest economy in the world. The decisions of resource providers to invest or not in the United States significantly affect the expansion of international liquidity; that is, the behavior of the American economy determines the level of international liquidity (Resende \& Amado, 2007). In line with this understanding, changes in the American interest rates are also expected to affect international liquidity and, as a result, bank liquidity in Brazil. Thus, an increase in American interest rates can encourage more international capital to flow into that country, to the detriment of investments in developing and, therefore, more risky economies such as Brazil. Although this reasoning applies specifically to shortterm liquidity, not reflecting a measure of diminished confidence in the domestic economy, but of better conditions for the investor in the American economy, the following hypothesis is formulated:

$\mathrm{H}_{7}$ : the structural liquidity of banking institutions in Brazil is negatively related with American interest rates.
The funds that financial institutions are obliged to deposit at the $\mathrm{CB}$, known as compulsory deposits, work as an economic policy mechanism. During the 2008 financial crisis, when a sharp retreat of liquidity occurred both in Brazil and abroad, compulsory deposits were used by the $\mathrm{CB}$ to mitigate these effects. Taking advantage of the significant volume of these deposits, the CB quickly made them available for the banking system, contributing to stabilizing the liquidity and supply of credit in the economy (CB, 2015).

Compulsory deposits reduce the volume of resources available for voluntary investment by institutions (Dantas et al., 2011). This leads to the understanding that an increase in compulsory deposits inhibits banks' long-term investments, since having scarcer resources directs them towards satisfying their short-term needs. As a result, the relationship with structural liquidity is positive, leading to the following hypothesis:

$\mathrm{H}_{8}$ : the structural liquidity of banking institutions in Brazil is positively related with the level of compulsory deposits in the economy.

When investigating the determinants of profitability, Rover, Tomazzia, and Fávero (2011) found a negative relationship between this and liquidity. According to the authors, at the same time as providing greater security, higher voluntary reserve values compromise profitable investments in loans and financing, which causes the negative relationship. The findings were compatible with the studies by Vodova (2011b), which focused on commercial banks in Slovakia, and by Moussa (2015), involving bank liquidity in Tunisia.

In the research by DeYoung and Jang (2016), the data suggest a positive relationship between liquidity and return in banks in the United States, with it being observed that financial returns [return on assets (ROA); return on equity (ROE)] followed an inverted $U$-shape in relation to the speeds of liquidity adjustments, with medium-sized banks operating very close to the sector's profit, which maximizes the speed of adjustments.

Based on these studies, the following hypothesis is formulated to be empirically tested:

$\mathrm{H}_{9}$ : the structural liquidity of banking institutions in Brazil is negatively related with the bank's level of return.

DeYoung and Jang (2016) observed how banks in the United States reacted in the past (1992 to 2012) to liquidity shocks that made them deviate from their benchmarks for this indicator. The results showed that one in every seven common and medium-sized banks in the United States 
were operating below the standard NSFR at the start of the financial crisis, with the breach rate increasing with the size of the bank. Analyzing the biggest institutions, more than half were unable to meet the standard NSFR simulated. Thus, it is inferred that, as banks increase in size, they establish lower liquidity targets, which results in the following hypothesis:

$\mathrm{H}_{10}$ : the structural liquidity of banking institutions in Brazil is negatively related with the size of the bank.

Vinhado and Belém (2013) found that Brazilian government banks presented a greater preference for liquidity in relation to private ones. The authors suggest that this possibly signals the fulfillment of the government role of these banks or their counter-cyclical position at some points in time, in order to irrigate the economy with liquidity to attenuate a recession by granting credit. Therefore, for this question, the following research hypothesis is tested:

$\mathrm{H}_{11}$ : the structural liquidity of banking institutions in Brazil is positively related to whether the institution is under government control.

According to DeYoung and Jang (2016), although both the stock market and the debt market serve as external liquidity resources for banks, the stock market predominates. Based on this assumption, inserting a dichotomous variable into the model to identify the banks whose shares were traded on the stock exchange, the authors find a positive relationship between this characteristic and the liquidity of the banking institutions. This gives support to the following hypothesis:

$\mathrm{H}_{12}$ : the level of structural liquidity of banking institutions in Brazil is positively related with whether they have shares publicly traded on the stock exchange.

It is possible that the structural liquidity of Brazilian banking institutions is related with the main activity carried out, since each type of bank is expected to manage its liquidity in order to meet it targets. Thus, DeYoung and Jang (2016) found that banks that have more branches generate more deposits, and banks that invest in housing finance use their deposits to fund their longterm investments, represented by residential mortgages. As these activities are typical of banks with a commercial portfolio, based on the findings of DeYoung and Jang (2016), the following hypothesis was formulated:

$\mathrm{H}_{13}$ : the level of structural liquidity of banking institutions in Brazil is positively related with their main type of activity.

After the 2008 crisis, the debate about financial regulation was renewed. The liquidity of the assets traded by banks is the principle of the proposal that resulted in Basel III. After the crisis, it was verified that banks' assets did not reflect their own liquidity, but rather derivations of the operating conditions of the markets (Vasconcelos, 2014).

According to Silva (2009), the rules adopted by the CB to adapt the National Financial System to the Basel Agreements contributed to bank operations assuming a clear operating standard, demonstrating more transparency and security. Aita (2010) states that the contagion from the international crisis suffered by the Brazilian economy reduced market liquidity, which required strategic measures by the $\mathrm{CB}$.

In his study of the effects of the global crisis on Brazil, Freitas (2009) states that liquidity only started flowing again in March of 2009, when the National Monetary Council (Conselho Monetário Nacional-CMN), via the Credit Guarantee Fund (Fundo Garantidor de Crédito - FGC), established special protection and restored confidence in the market. For Vasconcelos (2014), this situation warrants the conservative requirements of the Basel Agreement, using minimum capital as a liquidity buffer in extreme conditions; when there is increased uncertainty, banks make use of greater liquidity security buffers.

Thus, the following hypothesis was formulated, in order to analyze the relationship between the structural liquidity of banking institutions in Brazil and the Basel agreements:

$\mathrm{H}_{14}$ : the level of structural liquidity of banking institutions in Brazil is positively related with the validity period of the Basel III Agreement.

\section{METHODOLOGY}

To carry out the empirical tests, as well as specifying the model to be used as a reference, an important step consists of defining the way to measure the variable of interest, the SLI. 


\subsection{Definition of the Proxy for the SLI}

Considering that the NSFR is not yet regulated in Brazil and that the SLI published in the REF cannot be used for this study, as it only presents aggregate data for the system and uses information that is unavailable to external users - such as settlement and custody system data, for example - a proxy was developed for the SLI, as summarized in equation 1 .

$$
\mathrm{SLI}_{\mathrm{it}}=\frac{\text { Stable Resources }_{\text {it }}}{\text { Long-Term Investments }_{\text {it }}}
$$

in which stable resources are composed of total deposits, loans, and transfers obtained from other institutions in the country (generally development banks and constitutional funds) or abroad (head office of foreign institutions or multilateral bodies), treasury bills, and obligations represented by bonds and securities abroad, and longterm investments correspond to naturally long-term investments, composed of so-called unusual assets (those that do not form part of the bank giro system), credit and commercial lease operations, and bonds and securities classified in accounting as available for sale or kept until maturity. These assets are naturally long-term and need a stable source of resources.

\subsection{Definition of the Model}

Having defined the dependent variable, model 2 was developed to test the research hypotheses and the relationship between the structural liquidity of Brazilian banking institutions and the macroeconomic, characteristic, and regulatory variables.

$$
\begin{aligned}
S L I_{i t}=\beta_{0}+ & \beta_{1} G D P_{t}+\beta_{2} B I_{t}+\beta_{3} E X C_{t}+\beta_{4} C R_{t}+\beta_{5} B T_{t}+\beta_{6} I R_{t}+\beta_{7} A I_{t}+\beta_{8} C D_{t} \\
& +\beta_{9} R O E_{i t}+\beta_{10} S I Z_{i t}+\beta_{11} G O V_{i t}+\beta_{12} T R D_{i t}+\beta_{13} T C B_{t}+\beta_{14} B 3_{t}+\mu_{i t}
\end{aligned}
$$

in which $\mathrm{SLI}_{\mathrm{it}}$ is the proxy for the SLI of the $\mathrm{i}$-th financial institution in period $t$, as according to equation $1, G P_{t}$ is the variation in GDP at market prices in period $t, \mathrm{BI}_{\mathrm{t}}$ is the basic interest rate of the economy - Special System for Settlement and Custody (Selic) - deflated by the Consumer Price Index (IPCA) in period $t, \mathrm{EXC}_{\mathrm{t}}$ is the final period selling exchange rate deflated by the IPCA in period $t, \mathrm{CR}_{\mathrm{t}}$ is the country-risk measured by the Emerging Markets Bond Plus Index (EMBI+) calculated by JP Morgan bank in period $t, \mathrm{BT}_{\mathrm{t}}$ is the ratio of the balance of trade to GDP in period $t, \mathrm{IR}_{\mathrm{t}}$ is the ratio of international reserves to GDP in period $t, \mathrm{AI}_{\mathrm{t}}$ is the American interest rate in period $t, \mathrm{CD}_{\mathrm{t}}$ is the ratio of compulsory deposits to the broad monetary base in period $t, \mathrm{ROE}_{\mathrm{t}}$ is the profitability indicator (return on equity) in period $t, \mathrm{SIZ}_{\mathrm{it}}$ is the natural logarithm of total assets in period $t, \mathrm{GOV}_{\mathrm{it}}$ is the dichotomous variable that represents the legal nature of the bank, taking the value 1 if the financial institution is controlled by the government and 0 for other controls,
$\mathrm{TRD}_{\mathrm{it}}$ is the dichotomous control variable that indicates whether the financial institutions used in the sample are publicly traded on the São Paulo Stock, Commodities, and Futures Exchange (BM\&FBovespa) in 2017 and is 0 for the rest, $\mathrm{TCB}_{\mathrm{it}}$ is the dichotomous control variable that, based on the type of consolidated banking informed by the $\mathrm{CB}$, indicates whether the financial institutions used in the sample have a commercial portfolio in 2017 and is 0 for the rest, $\mathrm{B} 3_{\mathrm{t}}$ is the dichotomous variable that represents the validity period of the Basel III Agreement, taking the value 1 for the periods as of October of 2013 and 0 for the rest, and $\mathrm{u}_{\mathrm{it}}$ is the random error of the regression, supposedly $\sim$ i.i.d. $\mathrm{N}\left(0, \sigma^{2}\right)$.

Considering the research hypotheses and model 2 , the relationships between the independent variables and the structural liquidity of the banks that operate in Brazil are expected to be statistically significant and the sign of the coefficients of each of them is expected to observe the relationship presented in Table 1.

\section{Table 1}

Relationship between hypotheses, independent variables, and expected sign for the regression parameters

\begin{tabular}{ccccccccccccccc}
\hline Hypotheses & $\mathbf{H}_{\mathbf{1}}$ & $\mathbf{H}_{\mathbf{2}}$ & $\mathbf{H}_{\mathbf{3}}$ & $\mathbf{H}_{\mathbf{4}}$ & $\mathbf{H}_{\mathbf{5}}$ & $\mathbf{H}_{\mathbf{6}}$ & $\mathbf{H}_{\mathbf{7}}$ & $\mathbf{H}_{\mathbf{8}}$ & $\mathbf{H}_{\mathbf{9}}$ & $\mathbf{H}_{\mathbf{1 0}}$ & $\mathbf{H}_{\mathbf{1 1}}$ & $\mathbf{H}_{\mathbf{1 2}}$ & $\mathbf{H}_{\mathbf{1 3}}$ & $\mathbf{H}_{\mathbf{1 4}}$ \\
\hline Variables & GDP & $\mathrm{BI}$ & $\mathrm{EXC}$ & $\mathrm{CR}$ & $\mathrm{BT}$ & $\mathrm{IR}$ & $\mathrm{Al}$ & $\mathrm{CD}$ & $\mathrm{ROE}$ & $\mathrm{SIZ}$ & $\mathrm{GOV}$ & TRD & TCB & B3 \\
\hline Expected sign & - & - & + & - & - & + & - & + & - & - & + & + & + & + \\
\hline
\end{tabular}

$B 3=$ dummy variable, which is 1 in the validity period of Basel III and 0 in the rest; $B T=$ ratio of the balance of trade to gross domestic product $(G D P) ; E X C=$ exchange rate variation; $C D=$ ratio of compulsory deposits to the broad monetary base; $A l=$ American interest rate; TRD = dummy variable, taking 1 for a financial institution publicly traded on the stock exchange or 0 otherwise; GDP = variation in GDP; GOV = dummy variable, taking 1 if the financial institution is controlled by the government and 0 otherwise; $I R=$ ratio of international reserves to $G D P ; R O E=$ profitability indicator (return on equity); $C R=$ country-risk measured by the Emerging Markets Bond Index Plus (EMBI+); SIZ = natural logarithm of total assets; TCB = dummy variable, taking 1 for a financial institution with a commercial portfolio and 0 otherwise; SIZ = natural logarithm of total assets.

- = negative $+=$ positive.

Source: Elaborated by the authors. 
The natural statistical technique to test the research hypotheses was the multiple regression with panel data, given the widespread availability of data related to a large number of banking institutions during a time period considered to be long and significant.

\subsection{Sample}

To carry out the empirical tests, the macroeconomic data series and the monthly accounting information were considered for a sample of 184 financial conglomerates or individual institutions not forming part of conglomerates, in the period from June 2002 to December 2014 (151 months), resulting in $\mathrm{T} x \mathrm{~N}=3,312$ observations.

The definition of the start of the period studied (June 2002) is warranted by the start of the validity period of the accounting rules that address the accounting classification of bonds and securities for trading, available for sale, or kept until maturity. Institutions that did not have the information needed to determine the proxy for the SLI were also excluded from the sample.

The data for the variables SLI, BI, BT, IR, CD, ROE, SIZ, GOV, and TCB were collected from the web pages of the CB. The data for the GDP variable were taken from the Brazilian Institute of Geography and Statistics (IBGE) and the EXC and CR variables were taken from the Institute of Applied Economic Research (IPEA). The International Monetary Fund (IMF) was the source of the $\mathrm{AI}$ variable and the $\mathrm{B} 3$ variable applied as of the date the Basel III Agreement was published. The TRD variable combined information from the $\mathrm{CB}$ with information from the BM\&FBovespa.

\section{RESULTS ANALYSIS}

The calculation of the descriptive statistics shows that the values of the central tendency measures (mean, median) are approximate for most of the variables, characterizing a normal distribution of data, which although asymmetric have no accentuated deviations, and is confirmed by the kurtosis, which presents values greater than 0.263 , indicating platykurtic curves (heavy tails) for the variables, as can be verified in Table 2 .

Table 2

Descriptive statistics of the non-dichotomous variables

\begin{tabular}{cccccccccccccc}
\hline & SLI & GDP & BI & EXC & CR & BT & IR & AI & CD & ROE & SIZ \\
\hline Mean & 1.21 & 0.01 & 0.01 & 0.00 & 0.40 & 0.02 & 1.32 & 0.00 & 0.08 & 0.02 & 8.52 \\
\hline Median & 0.95 & 0.01 & 0.01 & -0.01 & 0.24 & 0.02 & 1.37 & 0.00 & 0.07 & 0.02 & 8.55 \\
\hline Maximum & 9.96 & 0.03 & 0.02 & 0.28 & 2.40 & 0.08 & 1.95 & 0.00 & 0.14 & 1.47 & 15.90 \\
\hline Minimum & 0.00 & -0.01 & -0.01 & -0.15 & 0.14 & -0.02 & 0.61 & 0.00 & 0.03 & -23.35 & 0.21 \\
\hline $1^{\text {st }}$ quartile & 0.72 & 0.01 & 0.00 & -0.03 & 0.20 & 0.01 & 0.97 & 0.00 & 0.06 & 0.00 & 10.32 \\
\hline $3^{\text {rd }}$ quartile & 1.28 & 0.02 & 0.01 & 0.02 & 0.42 & 0.04 & 1.69 & 0.00 & 0.10 & 0.05 & 12.83 \\
\hline Standard deviation & 1.23 & 0.01 & 0.00 & 0.06 & 0.40 & 0.02 & 0.39 & 0.00 & 0.03 & 0.34 & 2.61 \\
\hline Asymmetry & 3.62 & -0.30 & -0.07 & 1.65 & 3.02 & 0.30 & -0.04 & 1.02 & 0.50 & -56.36 & 0.18 \\
\hline Kurtosis & 19.21 & 2.55 & 5.72 & 9.00 & 12.75 & 2.30 & 1.70 & 2.60 & 2.56 & 3.57 & 3.20
\end{tabular}

$B T=$ ratio of the balance of trade to gross domestic product $(G D P) ; E X C=$ exchange rate variation; $C D=$ ratio of compulsory deposits to the broad monetary base; $S L I=$ proxy for the structural liquidity index as according to equation $1 ; A I=A m e r i c a n$ interest rate; $G D P=$ variation in $G D P ; I R=$ proportion of international reserves over $G D P ; R O E=$ profitability indicator (return on equity); $C R=$ country-risk measured by the Emerging Markets Bond Index Plus (EMBI+); SIZ = natural logarithm of total assets; $B I=$ basic interest rate of the economy.

Source: Elaborated by the authors.

So that it is clearer to the reader, Table 3 shows the evolution of the macroeconomic variables in 12 months. 
Table 3

Evolution of the macroeconomic variables

\begin{tabular}{ccccccccc}
\hline & GDP & BI & EXC & CR & BT & IR & Al & CD \\
\hline 2002 & $3.05 \%$ & $23.03 \%$ & $3.46 \%$ & $14.46 \%$ & $2.96 \%$ & $0.86 \%$ & $1.24 \%$ & $4.25 \%$ \\
\hline 2003 & $1.14 \%$ & $16.91 \%$ & $2.87 \%$ & $4.63 \%$ & $4.33 \%$ & $1.00 \%$ & $0.98 \%$ & $6.59 \%$ \\
\hline 2004 & $5.76 \%$ & $17.50 \%$ & $2.63 \%$ & $3.82 \%$ & $5.02 \%$ & $0.91 \%$ & $2.16 \%$ & $6.39 \%$ \\
\hline 2005 & $3.20 \%$ & $18.24 \%$ & $2.33 \%$ & $3.11 \%$ & $4.93 \%$ & $0.79 \%$ & $4.16 \%$ & $6.43 \%$ \\
\hline 2006 & $3.96 \%$ & $13.19 \%$ & $2.13 \%$ & $1.92 \%$ & $4.18 \%$ & $0.74 \%$ & $5.24 \%$ & $6.12 \%$ \\
\hline 2007 & $6.07 \%$ & $11.18 \%$ & $1.76 \%$ & $2.21 \%$ & $2.84 \%$ & $1.22 \%$ & $4.24 \%$ & $6.02 \%$ \\
\hline 2008 & $5.09 \%$ & $13.66 \%$ & $2.33 \%$ & $4.28 \%$ & $1.44 \%$ & $1.36 \%$ & $0.16 \%$ & $6.07 \%$ \\
\hline 2009 & $-0.13 \%$ & $8.65 \%$ & $1.73 \%$ & $1.92 \%$ & $1.50 \%$ & $1.52 \%$ & $0.12 \%$ & $3.11 \%$ \\
\hline 2010 & $7.53 \%$ & $10.66 \%$ & $1.66 \%$ & $1.89 \%$ & $0.90 \%$ & $1.42 \%$ & $0.18 \%$ & $9.17 \%$ \\
\hline 2011 & $3.97 \%$ & $10.90 \%$ & $1.87 \%$ & $2.08 \%$ & $1.13 \%$ & $1.52 \%$ & $0.07 \%$ & $13.75 \%$ \\
\hline 2012 & $1.92 \%$ & $7.16 \%$ & $2.03 \%$ & $1.42 \%$ & $0.81 \%$ & $1.81 \%$ & $0.16 \%$ & $11.11 \%$ \\
\hline 2013 & $3.00 \%$ & $9.90 \%$ & $2.32 \%$ & $2.24 \%$ & $0.13 \%$ & $1.79 \%$ & $0.09 \%$ & $9.70 \%$ \\
\hline 2014 & $0.50 \%$ & $11.58 \%$ & $2.64 \%$ & $2.59 \%$ & $-0.19 \%$ & $1.82 \%$ & $0.12 \%$ & $9.79 \%$ \\
\hline
\end{tabular}

$B T=$ ratio of the balance of trade to gross domestic product (GDP) in 12 months; EXC = annual real exchange rate variation; $C D=$ ratio of compulsory deposits to the broad monetary base in 12 months; $A I=$ annual effective American interest rate; $G D P=$ variation in GDP at market prices in 1 year; $I R=$ ratio of international reserves, net concept, to GDP in 12 months; $C R=$ country-risk measured by the Emerging Markets Bond Index Plus (EMBI+) at the end of the period; BI = basic interest rate of the economy (p.a.).

Source: Elaborated by the authors.

Prior to estimating model 2, procedures were adopted to verify whether the conditions that ensured robust results were met. The multicollinearity risk was assessed using the correlation matrix between the explanatory variables of the model.

Considering the rule suggested by Gujarati and Porter (2011), that there is a relevant risk of multicollinearity when the correlation reaches the threshold of 0.8 , the results show that the BT and IR variables should not be tested together, but in separate models.

A more robust investigation of the multicollinearity problem is carried out via an analysis of the variance inflation factor (VIF). The VIF of an independent variable is obtained via $V I F_{\mathrm{k}}=\left(1-R_{\mathrm{k}}^{2}\right)^{-1}$, in which $V I F_{k}$ is the VIF of the $\mathrm{k}$-th independent variable and $\mathrm{R}_{\mathrm{k}}{ }_{\text {is }}$ is the coefficient of determination of the regression of the $\mathrm{k}$-th independent variable in relation to the other independent variables. The literature indicates that VIFs greater than 4 warrant deeper investigation, while VIFs greater than 10 indicate serious multicollinearity problems. Given the result of the correlation matrix, the decision was taken to analyze the VIFs of the explanatory variables of the proposed models, whose result is in Table 4.

The VIF analysis shows a value greater than 4 for the IR variable and close to 4 for the BT variable, reinforcing the decision that these variables should not be tested together, but in separate regressions.

Table 4

Variance inflation factors of the non-dichotomous explanatory variables

\begin{tabular}{ccccccccccc}
\hline Variable & GDP & BI & EXC & CR & BT & IR & Al & CD & ROE & SIZ \\
\hline$R^{2}$ & 0.339 & 0.477 & 0.205 & 0.464 & 0.727 & 0.835 & 0.590 & 0.341 & 0.006 & 0.005 \\
\hline VIF & 1.514 & 1.911 & 1.258 & 1.867 & 3.665 & 6.050 & 2.441 & 1.516 & 1.006 & 1.005 \\
\hline BT
\end{tabular}

$B T=$ ratio of the balance of trade to gross domestic product (GDP); $E X C=$ exchange rate variation; $C D=$ ratio of compulsory deposits to the broad monetary base; VIF = variance inflation factor; $A I=$ American interest rate; $G D P=v a r i a t i o n$ in $G D P ; I R$ = ratio of international reserves to GDP; $R O E=$ profitability indicator (return on equity); $C R=$ country-risk measured by the Emerging Markets Bond Index Plus (EMBI+); SIZ = natural logarithm of total assets; BI = basic interest rate of the economy.

Source: Elaborated by the authors.

The verification of the presence of unit roots was carried out using the Im, Pesaran, and Shin (IPS), ADF-Fisher, and PP-Fisher tests in all the series. The results reveal that, with the exception of the IR variable, all the variables are stationary according to the IPS and ADF-Fisher tests.
The AI variable is stationary in the IPS and ADF-Fisher tests, and not stationary only in the PP-Fischer test. The IR variable is not stationary in the three tests used. This, however, does not compromise the robustness of the regressions, given that there is no spurious regression 
when only one of the variables included in the regression is not stationary (Noriega \& Ventosa-Santaularia, 2007).

\subsection{Analysis of the Determinants of Bank Structural Liquidity}

To test the statistical significance of the explanatory variables for the structural liquidity of the banks that operate in Brazil, represented by the SLI, two estimations of model 2 were carried out, alternately and separately using the BT and IR variables, due to the multicollinearity risk highlighted in the previous section.

In general, the panel regression estimations can be carried out using three methods: pooled regression, fixed effects, and random effects. As is customary, first the redundant fixed effects test was used (in order to test the null hypothesis that the fixed effects are redundant against the alternative hypothesis of significant fixed effects), which would mean that the pooled regression would be appropriate. In the test carried out, the null hypothesis that the cross-sectional fixed effects are redundant was strongly rejected, both in the F version and in the likelihood function version $\left(\chi^{2}\right)$ of the test, indicating the choice of the fixed effects regression. Despite this result, the decision was made to present, in the regression results, the result of the pooled regressions, for comparison purposes. The result of the redundant fixed effects test is shown in Table 5.

Table 5

Redundant fixed effects tests

\begin{tabular}{ccccccc}
\hline & \multicolumn{3}{c}{ Estimation I } & \multicolumn{2}{c}{ Estimation II } \\
\hline Tests & Statistic & g.I. & p-value & Statistic & g.I. & p-value \\
\hline F cross-section & 134.982 & -181.192 & 0.000 & 134.937 & -181.192 & 0.000 \\
\hline Chi-squared cross-section & $15,923.488$ & 181.000 & 0.000 & $15,919.902$ & 181.000 & 0.000 \\
\hline
\end{tabular}

Source: Elaborated by the authors.

Next, an attempt was made to apply the Durbin-WuHausman test to support the decision regarding the fixed effects versus random effects estimation (Nakamura \& Nakamura, 1981). Unfortunately, the Durbin-Wu-Hausman statistic cannot be calculated, since the assumptions associated with this statistic are not compatible with choosing an estimation of robust standard errors in regards to heteroskedasticity using the White variance-covariance matrix used to control heteroskedasticity, as described below. However, for comparison purposes, the regression was estimated with random effects, having produced an $\mathrm{R}^{2}$ of only 0.0140 , against an $\mathrm{R}^{2}$ of 0.5701 from the estimation with fixed effects, revealing that the latter fit the data much better. In light of these results, the decision was made to keep the estimation with cross-sectional fixed effects, with robust standard errors.

There are still two additional problems in this estimation. The ROE variable is one of the regressors in the model, contributing to explaining the SLI. However, the SLI, in turn, surely contributes to explaining ROE. This situation of simultaneity results in ROE being an endogenous variable, thus being correlated with the residuals of the regression, and therefore causing biased and inconsistent coefficients. One solution to this problem is to use the two-stage least squares (2SLS) estimation or the generalized method of moments (GMM). In this study, 2SLS was chosen, which estimates biased, but consistent coefficients, which is guaranteed in this study, given the sample size, with 3,312 observations.
The other problem is the inevitability of heteroskedasticity of the residuals occurring, given the variability of the sample, which would produce inefficient standard errors, leading to probable type II inferential errors. To control this probable heteroskedasticity, the option of the White variance-covariance matrix was used to produce robust standard errors in the presence of heteroskedasticity.

Therefore, four estimations were carried out: two with pooled regression using 2SLS, with estimation of robust standard errors and alternating the BT and IR variables, and another two with cross-sectional fixed effects using 2SLS, with robust standard errors, also alternating the same variables, in order to avoid multicollinearity.

The results are consolidated in Table 6. Hypothesis $\mathrm{H}_{1}$ assumes a negative relationship between the structural liquidity of the banking institutions and the level of economic activity (GDP) of the country. The results of the estimations in both models do not confirm the hypothesis constructed based on the results of Aspachs et al. (2005), Vodova (2011a), and Vinhado and Belém (2013). One possibility for this result is that the literature used as a reference considered short-term liquidity and that the long-term relationship undergoes different effects from the level of economic activity. The empirical evidence suggests that banks can bring forward or make gradual adjustments in their structure of investments and long-term resources, depending on the level of economic activity, which is not captured in the model. 
Table 6

Results of the estimation of model 1 to identify the determinants of structural liquidity

Model tested:

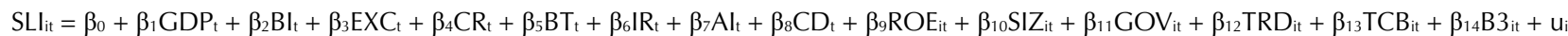

Instruments for 2SLS

C, GDP, GDP(-1), BI, BI(-1), EXC, EXC(-1), CR, CR(-1), ROE(-1), GOV, SIZ, BT, AI, CD, IR, TRD, B3, TCB

\begin{tabular}{|c|c|c|c|c|c|c|c|c|c|c|c|c|}
\hline \multirow{3}{*}{$\begin{array}{l}\text { Dep. } \\
\text { Var. }\end{array}$} & \multicolumn{6}{|c|}{ Pooled } & \multicolumn{6}{|c|}{ Fixed Effects } \\
\hline & \multicolumn{3}{|c|}{ Estimation I (BC) } & \multicolumn{3}{|c|}{ Estimation II (RI) } & \multicolumn{3}{|c|}{ Estimation I (BC) } & \multicolumn{3}{|c|}{ Estimation II (RI) } \\
\hline & Coef. & p-value & Sig. & Coef. & p-value & Sig. & Coef. & p-value & Sig. & Coef. & p-value & Sig. \\
\hline C & 0.587 & 0.000 & $* * *$ & 0.491 & 0.000 & $* * *$ & 1.056 & 0.000 & $* * *$ & 0.910 & 0.000 & $* * *$ \\
\hline GDP & 0.853 & 0.212 & & 1.213 & 0.100 & & 0.158 & 0.809 & & 0.733 & 0.301 & \\
\hline $\mathrm{BI}$ & -3.214 & 0.029 & $* *$ & -3.994 & 0.007 & $* * *$ & -3.069 & 0.021 & $* *$ & -3.224 & 0.016 & $* *$ \\
\hline EXC & 0.258 & 0.017 & $* *$ & 0.373 & 0.000 & $* * *$ & 0.299 & 0.005 & $* * *$ & 0.415 & 0.000 & $* * *$ \\
\hline CR & -0.161 & 0.000 & $* * *$ & -0.180 & 0.000 & $* * *$ & -0.196 & 0.000 & $* * *$ & -0.209 & 0.000 & $* * *$ \\
\hline BT & -1.647 & 0.000 & $* * *$ & & & & -1.805 & 0.000 & $* * *$ & & & \\
\hline IR & & & & 0.052 & 0.071 & $*$ & & & & 0.078 & 0.001 & $* * *$ \\
\hline $\mathrm{Al}$ & -3.260 & 0.473 & & -5.594 & 0.286 & & 6.515 & 0.104 & & 6.420 & 0.148 & \\
\hline $\mathrm{CD}$ & 0.809 & 0.000 & $* * *$ & 0.789 & 0.000 & $* * *$ & 0.520 & 0.008 & $* * *$ & 0.477 & 0.019 & $* *$ \\
\hline ROE & 0.083 & 0.000 & $* * *$ & 0.084 & 0.000 & $* * *$ & 0.027 & 0.008 & $* * *$ & 0.028 & 0.008 & $* * *$ \\
\hline SIZ & 0.082 & 0.000 & $* * *$ & 0.082 & 0.000 & $* * *$ & 0.030 & 0.004 & $* * *$ & 0.030 & 0.003 & $* * *$ \\
\hline GOV & -0.258 & 0.000 & $* * *$ & -0.258 & 0.000 & $* * *$ & & & & & & \\
\hline TRD & -0.231 & 0.000 & $* * *$ & -0.231 & 0.000 & $* * *$ & & & & & & \\
\hline TCB & 0.063 & 0.000 & $* * *$ & 0.062 & 0.000 & $* * *$ & & & & & & \\
\hline B3 & -0.038 & 0.064 & * & -0.030 & 0.160 & & -0.065 & 0.001 & * & -0.059 & 0.003 & $* * *$ \\
\hline
\end{tabular}

$B 3=$ dummy variable, taking 1 in the validity period of Basel III and 0 in the rest; BT = ratio of the balance of trade to gross domestic product $(G D P) ; E X C=$ exchange rate variation; $C D=$ ratio of compulsory deposits to the broad monetary base; $S L I=$ proxy for the structural liquidity index as according to equation 1; Al=American interest rate; TRD = dummy variable, taking 1 for a financial institution publicly traded on the stock exchange or 0 otherwise; GDP = variation in GDP; GOV = dummy variable, taking 1 for a financial institution controlled by the government and 0 otherwise; $I R=$ ratio of international reserves to GDP; ROE = profitability indicator (return on equity); $C R=$ country risk measured by the Emerging Markets Bond Index Plus (EMBI+); SIZ = natural logarithm of total assets; TCB = dummy variable, taking 1 for a financial institution with a commercial portfolio or 0 otherwise; $\mathrm{BI}=$ basic interest rate of the economy.

$* * *, * *, *=$ level of significance of the parameters at $1 \%, 5 \%$, and $10 \%$, respectively.

Source: Elaborated by the authors.

The negative relationship expected between structural liquidity and the level of the basic interest rate (BI) was confirmed in both models, corroborating hypothesis $\mathrm{H}_{2}$. This evidence confirms and reinforces the results of Oreiro (2005) and Vinhado and Belém (2013), in which it can be found that an increase in the interest rate of public debt will lead a bank to increase the interest rate on its investments, discouraging borrowers of long-term loans, as well as incentivizing the flow of resources into short-term operations, in order to take advantage of gains derived from the increase in interest rates.

In the third hypothesis, the relationship between bank structural liquidity and exchange rate variations (EXC) was tested. The tests with both estimations showed that there was a positive and significant relationship between the variables, confirming $\mathrm{H}_{3}$. These results may be associated with the difficulty found by banking institutions in timely anticipating the effects of exchange rate variations. In addition, the study by Primo et al. (2013) on profitability (which has a negative relationship with liquidity) corroborates the results of this research.

The country-risk (CR) effect on structural liquidity was the relationship tested by $\mathrm{H}_{4}$. The results of both estimations show a negative and statistically significant relationship between the variables, confirming the research hypothesis and converging with the evidence of Resende and Amado (2007) and Manhiça and Jorge (2012), who stated that an aversion to country-risk would cause an outflow of foreign resources from Brazil towards countries that are considered to be safer. This demonstrates that an increase in countryrisk, because it is a reflection of diminished confidence in relation to the domestic economy, more strongly affects 
stable resources than long-term investments, causing a negative effect on the structural liquidity of banks.

The relationship between structural liquidity and the balance of trade (BT) was the fifth hypothesis tested. The results of estimation I confirm the negative and statistically significant relationship, corroborating $\mathrm{H}_{5}$. This empirical evidence demonstrates that when the balance of trade improves, directly influencing the balance of current transactions, there is a favorable impact over the economy, since exports bring more resources into Brazil, which should translate into more investments - requiring more long-term bank credit, increasing the denominator of the SLI formula and, consequently, reducing the index.

In relation to international reserves (IR), the results of estimation II converge with the study by Resende and Amado (2007), according to which growth in the international reserves of peripheral countries is explained by periods of expansion in the supply of international liquidity and by the absorption by these economies of the possibilities of access to international financing. In summary, the empirical tests confirm the positive and statistically significant relationship between international reserves and the structural liquidity of Brazilian banks, thus corroborating hypothesis $\mathrm{H}_{6}$.

The relationship between interest rate changes in the United States and the structural liquidity of Brazilian banks is the seventh hypothesis tested. Based on the literature on current, short-term liquidity, a negative relationship was predicted between the American interest rate (AI) and the SLI in Brazil, which was confirmed in the pooled regression model, although it was not statistically significant. The results of the two estimations in the regression with fixed effects, however, showed positive signs and no statistical significance, leading to the rejection of $\mathrm{H}_{7}$. It is possible to understand this positive relationship found based on the assumption that interest rates in the United States negatively affect short-term liquidity in Brazil, but, as they do not involve diminished confidence in the domestic economy, they can end up positively affecting structural liquidity, through a reduction in the banks' long-term investments.

The relationship between the level of compulsory deposits (CD) and structural liquidity is the eighth research hypothesis tested. Confirming expectations, the empirical tests demonstrated a positive relationship with statistical significance between the variables, corroborating $\mathrm{H}_{8}$. Thus, it is understood that an increase in the level of banks' compulsory deposits positively affects structural liquidity, reducing the volume of resources directed at the institutions' long-term investments, which is consistent with the findings of Dantas et al. (2011), while the numerator of the SLI is not affected - the result is an increase in the value of the indicator.

The ninth research hypothesis of this study relates the level of profitability of each banking institution in Brazil with its structural liquidity. The negative relationship expected was not confirmed, which leads to the rejection of $\mathrm{H}_{9}$. The results demonstrated the positive and statistically significant association at $1 \%$ between return and structural liquidity in the estimations of both models, which suggests the possible arbitration of profits, as was already pointed out by King (2013) and DeYoung and Jang (2016), since in order to meet the NSFR standards, banks may be incentivized to reduce high-performance assets and increase stable resources, which has a positive effect on returns. The positive relationship indicates synchronicity between liquidity management and the profitability of Brazilian banks and corroborates the findings of DeYoung and Jang (2016) in the United States.

For large banks, the imposition of standards linked to the NSFR could have big and systematic effects on the supply of credit via the banking, political, and economic supervisors, if structural liquidity levels were below the minimum required in Basel III. The negative relationship between the size of the institution and bank structural liquidity was tested and rejected in $\mathrm{H}_{10}$, which leads to the understanding that the banks (independently of their size) have substantially increased their absolute liquidity levels, as well as reorganizing their balance sheet liquidity risk management practices.

$\mathrm{H}_{11}$ tested the possibility that Brazilian government banks would have a greater preference for liquidity in relation to private ones, in accordance with the study by Vinhado and Belém (2013), and the results reveal a negative, statistically significant relationship at $1 \%$ and indicate that both government and private banks are able to irrigate the economy with liquidity by granting credit. The signs in the pooled regression model are confirmed again and reveal a negative and statistically significant relationship, which leads to the rejection of $\mathrm{H}_{11}$.

Given the results found by DeYoung and Jang (2016), $\mathrm{H}_{12}$ expected a positive relationship between bank liquidity and having shares publicly traded on the stock exchange. The basis was that the stock market would be an external source of liquidity for banks, with greater relevance than the debt markets. However, $\mathrm{H}_{12}$ was not proven and a negative relationship was found in Brazil. The reason for this finding needs investigation, but it may be an indication of the fact that Brazil has relatively few institutions with publicly traded shares (only $12 \%$, or 22 of the 184 in the sample), revealing that this is not the most important source of liquidity for the banks. 
The type of activity carried out by the bank was expected to present a relationship with structural liquidity, which was investigated by $\mathrm{H}_{13}$. In this case, the hypothesis that banks with a commercial portfolio have a higher structural liquidity indicator was confirmed. The results indicate that this type of bank, due to its characteristics, can fund its long-term investments via its deposits, thus converging with the results of DeYoung and Jang (2016), who investigated this behavior through the value of mortgages (long-term investments) and number of (retail) branches.

Finally, the last hypothesis, $\mathrm{H}_{14}$, aims to verify whether the validity period of the Basel III Agreement had any relationship with the level of structural liquidity of the banks. A positive sign was expected, but the tests returned a negative and statistically significant sign, which generates inconclusive results. Possibly, another phenomenon may be dominating the effect of B3. This counter-intuitive result might suggest that, since the validity period (starting in October 2013) coincides with the start of a political and economic crisis in the country, this may have contaminated the variable of interest, since, as Krishnamurthy et al. (2016) state, bank liquidity performs an important role during financial crises. Thus, the study might not have captured the relationship with the Basel III Agreement, but rather the one between the Brazilian crisis and the liquidity of the banks, which occurred simultaneously and was not the object of this study. At any rate, hypothesis $\mathrm{H}_{14}$ was not confirmed.

\section{CONCLUSION}

The aim of this study was to identify the relationship between the structural liquidity of the banking institutions that operate in Brazil and macroeconomic variables, bank characteristic variables, and the banks' sensitivity to the implementation of the Basel III Agreement. For this, monthly accounting data was used for 184 financial conglomerates or individual institutions between the months of June 2002 and December 2014.

To determine the dependent variable representative of the SLI of the banking institutions, a proxy for the indicator used by the CB was used, formed by means of the ratio between long-term investments and stable capital. In addition, 14 research hypotheses were constructed that were the basis for the definition of the econometric model and the results analysis, and which set out the expected relationships between the level of structural liquidity of the institutions that operate in Brazil and the chosen variables.

The results, calculated with the use of pooled and fixed effects panel data regressions, demonstrated in Table 6, support the research hypotheses that the level of structural liquidity of banking institutions in Brazil has a statistically significant relationship in the expected direction, this being: (i) negative for positive variations in the interest rates, revealing that Brazilian banks reduce their long-term liquidity when interest rates rise $\left(\mathrm{H}_{2}\right)$; (ii) positive with positive variations in the exchange rates, confirming the assumption that the banks are unable to adequately anticipate variations in the currency market $\left(\mathrm{H}_{3}\right)$; (iii) negative with the Brazil-risk, showing the impact that diminished confidence in the domestic economy causes in terms of an outflow of investor resources and affecting structural liquidity $\left(\mathrm{H}_{4}\right)$; (iv) negative with the balance of trade, given that the balance of foreign transactions contributes to an increase in long-term investments, negatively affecting structural liquidity $\left(\mathrm{H}_{5}\right)$; (v) positive with international reserves, which have a negative relationship with the balance of trade, so that they tend to positively affect structural liquidity $\left(\mathrm{H}_{6}\right)$; (vi) positive with compulsory deposits, explaining that the level of structural liquidity increases when the level of compulsory deposits is raised by the inhibitor effect that they have over long-term investments $\left(\mathrm{H}_{8}\right)$; a significant relationship in the opposite direction was found, this being (vii) positive with returns, indicating the effective management of liquidity and returns of the banks in Brazil $\left(\mathrm{H}_{9}\right)$; (viii) positive with size, which reveals that the Brazilian banking institutions did not reduce their liquidity targets in the period analyzed; (ix) negative with government control and banks publicly traded on the BM\&FBovespa and positive with banks with a commercial portfolio, indicating a significant association between this type of institution and structural liquidity; (x) negative with the validity period of the Basel III Agreement, despite a positive relationship being expected, leading it to be believed that the study captured the effect of another phenomenon that was not investigated, which may have some relationship with the political and economic crisis in the country, which started in the period studied, and not with the regulatory variable itself. Finally, no relevant statistical relationship was found between the level of structural liquidity of the banking institutions and economic activity represented by GDP $\left(\mathrm{H}_{1}\right)$ and the American interest rates $\left(\mathrm{H}_{7}\right)$.

Standing out as limitations is the start of the validity period of the accounting standards that address the accounting classification of bonds and securities for trading, available for sale, and kept until maturity as of 2002, 
which limited the number of observations. In addition, the concept of structural liquidity, represented in this study by the SLI indicator as a proxy for the one developed and used managerially by the $\mathrm{CB}$, which is equivalent to the NSFR with recommended implementation as of 2018, as according to the Basel III Agreement, is relatively new and may not yet have been employed in other economic or crisis settings, which would make comparing the results found in the Brazilian case difficult.

However, as the research captured a statistically significant relationship between this period and bank liquidity, this may be associated not with the Basel agreement, but with another phenomenon that was not evaluated, suggesting a possible relationship with the deterioration in the economic fundamentals of the Brazilian economy, the beginning of which coincided with the validity period of that agreement. Thus, for future studies, we suggest deepening the research on the effect of the Brazilian economic crisis, which appears to be significant from 2013 onward, over the structural liquidity of the banks and other variables. In addition, we suggest an analysis of the relationships between the macroeconomic and regulatory variables and the level of bank structural liquidity, if possible, in other economies, such as that of the United States, in order to prove the results found, since, as DeYoung and Jang (2016) state, liquidity and lending indices are practiced by many banks in the country as a way of diagnosing liquidity risks.

\section{REFERENCES}

Aita, J. (2010). Determinantes de insolvência bancária no Brasil: identificação de evidências macro e microeconômicas (Master's Dissertation). Universidade do Vale dos Sinos, São Leopoldo.

Aspachs, O., Nier, E., \& Tiesset, M. (2005). Liquidity, banking regulation and the macroeconomy. Evidence on bank liquidity holdings from a panel of UK-resident banks. Retrieved from https://www.bis.org/bcbs/events/rtf05AspachsNierTiesset.pdf.

Banco Central do Brasil. (2012). Resolution n. 4,090, of May 24, 2012. Describes the liquidity risk management structure. Retrieved from http://www.bcb.gov.br/pre/normativos/ res/2012/pdf/res_4090_v1_O.pdf.

Banco Central do Brasil. (2015). Relatório de Estabilidade Financeira. Retrieved from http://www.bcb.gov.br/htms/ estabilidade/2015_10/refPub.pdf.

Bonfin, D., \& Kim, M. (2012). Risco de liquidez sistêmico. In Banco de Portugal, Relatório de Estabilidade Financeira (pp. 79-98). Lisboa: Banco de Portugal.

Borça, G. R., Jr., \& Torres, E. T., Filho. (2008). Analisando a crise do sub-prime. Revista do BNDES, 15(30), 129-159.

Capelletto, L. R. (2006). Mensuração do risco sistêmico no setor bancário com utilização de variáveis contábeis e econômicas (Doctoral Thesis). Faculdade de Economia e Administração, Universidade de São Paulo, São Paulo.

Cardoso, M. F. J. (2013). O impacto de Basileia III na oferta de crédito - O caso dos grupos GGD, BCP, BES, BPI, BST e BANIF (Master's Dissertation). Universidade do Porto, Porto.

Dantas, J. A., Medeiros, O. R., \& Capelletto, L. R. (2011). Determinantes do spread bancário ex-post no mercado brasileiro. Revista de Administração Mackenzie, 13(4), 48-74.

DeYoung, R., \& Jang, K. Y. (2016). Do banks actively manage their liquidity? Journal of Banking and Finance, 66(2016), 143-161.

Diamond, D. W., \& Dybvig, P. H. (1983). Bank runs, deposit insurance, and liquidity. Journal of Political Economy, 91(3), 401-419.

Flannery, M. J., \& Giacomini, E. (2015). Maintaining adequate bank capital: An empirical analysis of the supervision of European banks. Journal of Banking and Finance, 59 (C), 236-249.
Freitas, M. C. P. de (2009). Os efeitos da crise global no Brasil: aversão ao risco e preferência pela liquidez no mercado de crédito. Estudos Avançados, 23(66), 125-145.

Gideon, F., Petersen, M. A., Mukuddem-Petersen, J., \& Hlatshwayo, L. N. P. (2013). Basel III and the net stable funding ratio. ISRN Applied Mathematics, 2013, ID 582707.

Gobat, J., Yanase, M., \& Maloney, J. F. (2014). The net stable funding ratio: Impact and issues for consideration [Working Paper]. International Monetary Fund.

Gonçalves, R. M. L., \& Braga, M. J. (2008). Determinantes de risco de liquidez em cooperativas de crédito: uma abordagem a partir do modelo logit multinomial. Revista de Administração Contemporânea, 12(4), 1019-1041.

Gonzales-Hermosillo, B. (1999). Determinants of ex-ante banking system distress: A macro-micro empirical exploration of some recent episodes [Working Paper]. International Monetary Fund.

Gujarati, D. N., \& Porter, D. C. (2011). Econometria Básica (5. ed.). Porto Alegre: AMGH Editora Ltda.

King, M. R. (2013). The Basel III net stable funding ratio and bank net interest margins. Journal of Banking and Finance, 37(11), 4144-4156.

Krishnamurthy, A., Bai, J., \& Weymuller, C. H. (2016). Measuring liquidity mismatch in the banking sector [Working Paper]. National Bureau of Economic Research.

Luporini, V., \& Alves, J. (2010). Investimento privado: uma análise empírica para o Brasil. Economia e Sociedade, 19(3), 449-475.

Malik, M. F., \& Rafique, A. (2013). Commercial banks liquidity in Pakistan: Firm specific and macroeconomic factors. Romanian Economic Journal, 16(48), 139-154.

Manhiça, F. A., \& Jorge, C. T. (2012). O nível da taxa básica de juros e o spread bancário no Brasil: uma análise de dados em painel [Discussion paper]. Instituto de Pesquisa Econômica Aplicada.

Mishkin, F. S., \& Eakins, S. G. (2012). Financial markets \& institutions (7th ed.). Boston: Prentice Hall. 
Moussa, M. A. B. (2015). The determinants of bank liquidity: Case of Tunisia. International Journal of Economics and Financial, 5(1), 249-259.

Nakamura, A., \& Nakamura, M. (1981). On the relationships among several specification error tests presented by Durbin, Wu, and Hausman". Econometrica, 49(6): 1583-1588.

Noriega, A. E., \& Ventosa-Santaularia, D. (2007). Spurious regression and trending variables. Oxford Bulletin of Economics and Statistics, 69(3), 439-444.

Oreiro, J. L. (2005). Preferência pela liquidez, racionamento de crédito e concentração bancária: uma nova teoria póskeynesiana da firma bancária. Estudos Econômicos, 35(1), 101-131.

Paula, L. F. de, \& Lima, G. T. (1999). Teoria da firma bancária. Macroeconomia moderna: Keynes e a economia contemporânea. Rio de Janeiro: Campus.

Paula, L. F. R. de (1998). Comportamento dos bancos, posturas financeiras e ofertas de crédito: de Keynes a Minsky. Análise Econômica, 16(29), 21-38.

Primo, U. R., Dantas, J. A., Medeiros, O. R., \& Capelletto, L. R. (2013). Determinants of banking profitability in Brazil. BASE - Revista de Administração e Contabilidade da Unisinos, 10(4), 308-323.

Resende, M. F. C. de, \& Amado, A. M. (2007). Liquidez internacional e ciclo reflexo: algumas observações para a América Latina. Revista de Economia Política, 27(1), 41-59.
Rover, S., Tomazzia, E., \& Fávero, L. P. (2011). Determinantes econômico-financeiros e macroeconômicos da rentabilidade: evidências empíricas do setor bancário brasileiro. In Anais do Encontro da Anpad - EnANPAD. Rio de Janeiro, RJ. Retrieved from http://www.anpad.org.br/admin/pdf/FIN536.pdf

Silva, V. O. (2009). Determinantes da liquidez bancária na economia brasileira pós-acordos da Basileia: 1996-2009 (Master's Dissertation). Universidade Estadual de Maringá, Maringá.

Tabak, B. M., Guerra, S. M., Miranda, R. C., \& Souza, S. R. S. (2012). Teste de estresse para risco de liquidez: o caso do sistema bancário brasileiro [Discussion paper]. Banco Central do Brasil.

Tirole, J. (2011). Illiquidity and all its friends. Journal of Economic Literature, 49(2), 287-325.

Vasconcelos, D. de S. (2014). Regulação bancária, liquidez e a crise financeira: uma análise da proposta de regulação de liquidez em Basileia III (Doctoral Thesis). Universidade Federal do Rio de Janeiro, Rio de Janeiro.

Vinhado, F. S. da, \& Belém, V. C. (2013). Preferência pela liquidez dos bancos no Brasil: uma investigação empírica com dados em painel dinâmico. Revista de Gestão, Finanças e Contabilidade, 3(2), 24-38.

Vodova, P. (2011a). Liquidity of Czech commercial banks and its determinants. International Journal of Mathematical Models and Methods in Applied Sciences, 5(6), 1060-1067.

Vodova, P. (2011b). Determinants of commercial bank's liquidity in Slovakia. Retrieved from http://www.opf.slu.cz/kfi/icfb/ proc2011/pdf/65_Vodova.pdf. 